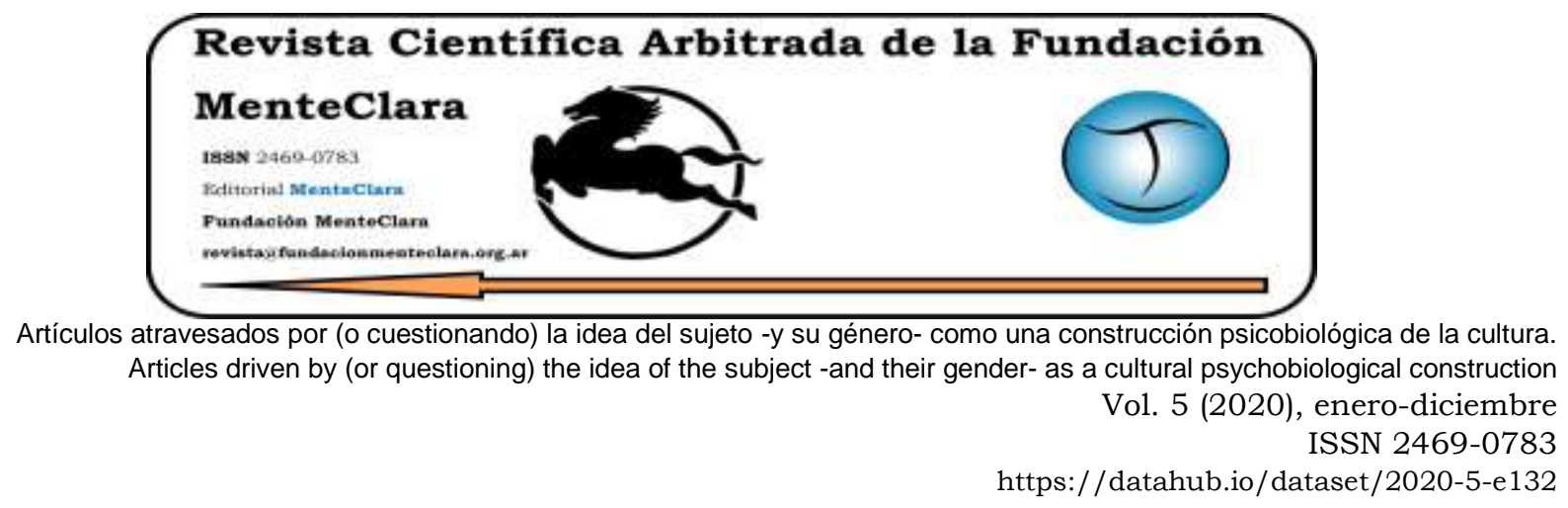

\title{
THE BEATIFIC EXPERIENCE OF BEING: A PHENOMENOLOGY OF THE CHAKRASAMVARA TANTRA
}

\author{
LA EXPERIENCIA BEATIFICA DEL SER: UNA FENOMENOLOGIA DEL \\ CHAKRASAMVARA TANTRA
}

Rudolph Bauer rbauer@rsbauer.net

Center for Consciousness Studies and Washington Center for Phenomenological and Existential Psychotherapy Studies. United States of America

Cómo citar este artículo / Citation: Bauer R. (2020). "The Beatific Experience of Being: A Phenomenology of The Chakrasamvara Tantra". Revista Cientifica Arbitrada de la Fundación MenteClara, Vol. 5 (132).

DOI: https://doi.org/10.32351/rca.v5.132

Copyright: (C) 2020 RCAFMC. Este artículo de acceso abierto es distribuido bajo los términos de la licencia Creative Commons Attribution 4.0 International License (CC BY 4.0). Recibido: 18/12/2019. Aceptado: 11/01/2020 Publicación online: 18/01/2020

Conflicto de intereses: None to declare.

\begin{abstract}
This article is a phenomenological elaboration of the Chakrasamvara Tantra. The Tibetan Chakrasamvara Tantra brings forth a naturalistic understanding of the process of the Embodiment of Being and the process of the invocation of the Bliss of Embodied Being. The Chakrasamvara Tantra, beautifully describes the experience of the Beatific Vision of Being, as well the invocation of the Beatific experience of Being, the Beatific experience of primordial luminous awareness.
\end{abstract}

\section{Resumen}

Este artículo es una elaboración fenomenológica del Chakrasamvara Tantra. El tibetano Chakrasamvara Tantra presenta una comprensión naturalista del proceso de la encarnación del Ser y el proceso de invocación de la bienaventuranza del Ser Encarnado. El Chakrasamvara Tantra, describe bellamente la experiencia de la visión 
beatífica del ser, así como la invocación de la experiencia beatífica del Ser, la experiencia beatífica de la conciencia luminosa primordial.

Keywords: tantra; Chakrasamvara; beatific vision; luminous awareness

Palabras Claves: tantra; Chakrasamvara; visión beatífica; conciencia luminosa 


\section{Introduction}

The Chakrasamvara experience of our Beatific Vision and our lived Beatific experience takes place within our life just as it is, and just as we are. The Chakrasamvara Tantra describes the foundational experience of Being and the Univocity of Being through which all hierarchal-ness is deconstructed. Within this deconstruction of hierarchy, a subtle unstructured luminous equality consciousness becomes present. The Univocity of Being means the complete sameness and complete oneness of Being. Human beings can bring forth the experience of the non-duality of equality consciousness within the phenomenological duality of human beings. This Univocal-ness means there is a difference within form, but not within essence, not within Being (Gray, 2007).

The qualities of Being are Spaciousness, Luminosity, Energy, and Knowingness. There are other qualities such a Purity, Compassion, and Self Manifestation. Our focus is on the Quality of Bliss, Beatific Bliss. Bliss is an ontological quality of Being. This ontological quality of Being infuses our personal and collective experience of existence.

The Chakrasamvara Tantra illuminates the Univocity of Being within phenomenological difference. Univocal-ness is a language description of the complete oneness and sameness of Being. Within Being and the selfmanifestation of Being, there is a oneness of non-hierarchal existence. The Univocal-ness is equality consciousness and the equal vision of the Beatific-ness of the Purity of Being as beings. In theological language God or Deus is neither above nor below and God is within everything and everyone as the Divinity of Being. God is a Univocal collective experience of Being.

In philosophical language Being is. Being is not a being. But Being selfmanifests as all beings and as the Being of all beings. In the language of 
Dzogchen all phenomena are the Dharmakaya. All phenomena are the Purity of the Dharmakaya. All beings are the self-manifestations of the ground of Being. The ground of Being is the Dharmakaya of Pure Potentiality. There is no ontological difference within the Oneness of the field of Being. There is a difference in form, but not within Being. This is pantheistic experience!

\section{Immanence of Bliss}

The Chakrasamvara is a Tantra elaborating within the field of immanence the inherent Bliss of Being and the Bliss within the phenomenological manifestation of Being. The Chakrasamvara Tantra sets forth the immanent path of self- liberation through the experience of the Bliss of Being. Chakrasamvara is a Tantra focused on the intrinsic experience of self-liberation in our life, just as it is and just as we are. The experience of the Bliss of Being is the source of self-liberation.

The Chakrasamvara Tantra is a discourse on and within the field of immanence. In this field of immanence, there is this foundational experience of equality consciousness and equal vision. The field of immanence is the field of Being as Oneness. Within the Chakrasamvara Tantra there is neither above nor below or better or best in this luminous field of the plane of immanence. The plane of immanence is the plane of the field of awareness infinite in its horizons, vast and multidimensional Oneness. The field of primordial awareness is within the immanence of the field of Being. Immanence means the essence of Being is within all phenomena and is within all experience and is completely within the self -manifestation of world. Immanence means within phenomena within us, within life is the luminous spacious field of Being. The field of Being is 
embodied within us and within the phenomena of the world. There is no beyond within the field of immanence.

The Chakrasamvara Tantra elaborates the Univocity of Being and the naturalistic equality of consciousness of the plane of immanence, the plane of the luminous field of Being. Being is not a being, but Being selfmanifests as the Being of all beings.

\section{Transcendental Forms of Liberation and Immanent Forms of}

\section{Liberation}

The foundational transcendental experience of the non-dualistic experience of self- liberation is simply "I Alone Exist". The foundational immanent experience of the non-dualistic experience of self-liberation within the field of immanence is simply that 'you and I' are indivisible within and as the non-dualistic field of Being. Within the field of immanence duality exists within non-duality and within non-duality duality exists. Equality consciousness is the experience of the univocalness of Being within the difference of all the forms of Being. Within the duality of beings, there is the non-duality of Being. And within the nonduality of Being, there is the duality of beings. Through our own being, we can experience Being itself. And through the being of another we can experience Being itself. We live in the sea of Being and we are within the sea of Being. We are the sea of Being.

\section{The Bliss of Existence is The Bliss of Being}

The Chakrasamvara is the tantra of innate Bliss of existing-ness. This existing-ness goes beyond the formulation of life and death of our singular incarnations. The Chakrasamvara is the tantra of the innate Bliss of Existing-ness. This existing-ness goes beyond the formulation of 
life and death of our singular incarnations. The Chakrasamvara is the Tantra of the embodiment of Bliss that is the very essence of the sphere of Being. Bliss is the essence of Being. Being is not a being, and Being manifests within us as infinite manifestations of beings, and these beings are the Being-ness of Being itself. Within Being there is only oneness, and the oneness is totally undisturbed by the difference of forms within beings and between beings. We are Being becoming beings who are alive in time and beings who become Being in deathlessness. We appear from Being as beings and we disappear as beings into Being. We re-appear from Being as beings, and again in time and through time we dis-appear back into Being. Being becoming beings is life and beings becoming Being is deathlessness.

\section{Embodiment of Being: Bliss Overcomes Suffering}

This Chakrasamvara Tantra is the tantra of the pervasiveness of the Bliss within our human experience of Being-ness, and this bliss overcomes suffering. This bliss is both within the realm of good and evil, and yet beyond the realm of good and evil. This bliss of the Beatific-ness of ontological Being is the Beatific embodiment of our own Being. We embody the Bliss of Being. We embody Being and we are embodied by Being within Being.

The Bliss of embodied human experience is the focus of the Chakrasamvara Tantra. This beatific experience is the bliss of our experience of the unfolding of our ongoing embodied continuity of Being. Our embodiment of Being becomes the medium of the field of Being unfolding within self-liberation. The body is the medium of the field of awareness which is the field of Being. The knowing of Being is awareness. Awareness knows Being and awareness is the knowingness of Being. 
This embodiment is the unfolding bringing forth of the luminous subtle sphere of luminous channels and luminous chakras of our Being in our embodiment. The subtle luminous energy field is of central importance within the Chakrasamvara Tantra. Our embodiment of Being is the embodiment of light becoming flesh and flesh becoming enlightened. As we embody the luminous Being of our being, we are simultaneously embodying the light of Being itself. The light of Being is the light of our awareness.

\section{Beatific Vision and Beatific Experience}

This beatific experience of Being can be experienced by us in every situation and in every context and in every unfolding event of Being. This beatific experience of Being unfolds both within pleasure as well as within pain. This beatific experience of Being unfolds both within beauty and within terror, within peace and within war, within love and within hate, within perversity and within purity.

A mantra which expresses this tantric dimension of experiencing Being is: Om Ah Hum Bodichitta Maha Suka Jnana Dhatu Ah. Bodhicitta is the Great Compassion. Maha Suka is the Great Bliss which is Compassion, Jnana is Direct Knowing of Being, Dhatu Ah means Direct Knowing of Being in every situation. The Beatific-ness of our luminous embodied experience of pure primordial awareness is the experience of the flesh of the world to use Merleau Ponty's language describing ontological embodiment (Morris, 2018). Human experience is the intertwining of mind, awareness, embodiment and Being. Human experience is both ontic and ontological to use Heideggerian language. In experience, we experience the phenomena of Being, and the Being of the phenomena (Capobianco, 2014). 


\section{The Beatific Field of Being}

Beatific experience means Beatific Knowing-ness, Beatific Being-ness and Beatific Radiance. The radiance of Being brings forth the unfolding of the beatific experience of our life just as it is. This beatific vision and experience of beatific -ness is continuously given and open to us within every experience and within all experience. This beatific experience is within the realm of our ongoing continuity of our experience of innate awareness of the field of Being. This beatific realm of human experience is not earned or merited. This beatific realm of experience is given to us. This beatific realm of experience comes with the territory of our manifested nature of Being. Beatific experience is the very nature of human awareness, human gnosis and human jnana. Beatific experience is the Bliss of Being.

The inherent divinity of our human experience, reflects the immanence of Being within us both as our personal experience and our collective experience. This Beatific experience of Vision and Bliss is not a transcendental experience beyond human phenomena and beyond our mind and beyond our embodiment. This Beatific experience and Beatific vision is manifested in all the different dimensions of our humanness. The Beatific experience is experienced and manifested in all the dimensions or kayas. This is the dimension of ordinary life world of Being, as well as the dimension of the archetypal manifestations of Being as well as the dimension of pure potentiality of Being! Beatific experience happens in each of the dimensions of this multidimensional world of our existing-ness.

The ongoing continuous experience of the radiance of the Being of self -illumination is fully experienced within the realm of immanence of Being. 
The ongoing experience of transcendence is hierarchical and dissociative.

The transcendental quest dissociates us, separates us from the immanence of divinity of appearance and experience. The dissociative and detachment of the transcendental quest can foreclose for us the experience of the Being of phenomena. Transcendental method separates and dissociates our beatific experience of the Being of phenomena from the realm of pure awareness. Transcendental methodologies are dissociative and remove us from the immediacy of Beatific Life in our ordinary life world and the immediacy of archetypal realm within our ordinary life world.

Transcendental methodology dissociates us from our beatific experience of external phenomena as well as our inner most phenomena of awareness.

\section{Awareness is the Gnosis/Jnana of Direct Knowing}

When you and I' become aware of our own awareness, we enter into direct knowing of gnosis or jnana. We enter into tantra. Tantra is the unfolding experience of awareness of awareness. In this awareness of awareness and through this field of awareness, we directly experience and directly know Being within Being itself. This gnosis, this jnana, this direct perception knows non-duality, knows oneness, knows indivisibleness.

Gnosis is the knowing of oneness. Gnosis is the knowing of nonduality and gnosis is the direct knowing of our direct perception of Luminous Being. Just as our awareness as gnosis knows the non-duality of Being within beings, our mind knows duality, our mind knows the duality of phenomena, and the duality within phenomena. Our awareness knows Being, and our awareness knows the Being of 
phenomena. Our mind knows form, our mind knows the form of beings and things. Our mind knows phenomena both subtle and gross phenomena. Our mind knows difference.

So when we integrate our mind into our awareness field, into our gnosis, into our field of direct knowing of Being, we can know the duality of phenomena within the non-duality of Being; and we can know nonduality of Being within the duality of beings. This direct knowing of Being within and through phenomena is the immediate unfolding of selfliberation in our life. The experiencing the Being of phenomena is self liberation. To experience the Being of phenomena is to experience Bliss. To experience the Being of our own Being is to experience the Bliss of Being.

\section{Mind as a Knower of Forms, Awareness as a Knower of Being}

We have two ways of knowing. Our mind knows forms, things, both subtle and gross. Our mind knows dualities, our mind knows me and you, us and them, this and that. Our mind knows entities and beings, our mind knows time. Our mind knows difference. Our mind knows thoughts, our mind knows affects, emotions and feelings. Our mind knows sensation, our mind knows memory. Our mind knows images of memory. Our mind knows phenomena. Our mind knows the phenomena of otherness, our mind knows the dualities of phenomena and the dualities within phenomena (Bauer, 2019 a).

Our awareness knows Being directly and our awareness knows the Being-ness of Beings directly. Our awareness knows the Bliss of Being, the Bliss of Being-ness, the Bliss of Existing. Our awareness knows timelessness. Our awareness does not know forms. Our awareness does not know emotions and does not know affective states. Our awareness 
knows spaciousness, our awareness knows luminosity, our awareness knows energy, our awareness knows awareness within ourselves and within others. Our awareness knows timelessness, and our awareness knows timelessness within time. Awareness knows the bliss of Being within beings.

Bliss is not an affect and Bliss is not an emotion. Bliss is not a affect of our mind and bliss is not an emotion of our mind. The experience of bliss is not a function of our mind. Bliss is the experience of the manifestation of Being as beings, including our own Being. This manifestation of Being is experienced within the field of our awareness. Bliss is the experience of our awareness knowing and experiencing Being. Awareness is the direct knowingness of Being. Bliss is the nature of Being and Bliss is the experience of Being including our own Being and the Being of our own innermost awareness. The experience of Bliss is intrinsic to the experience of Being. Bliss is the innate sense of Being. Bliss is our sense of the Being of phenomena. Bliss can be the sense of our experience of the Being of a person. Bliss is the sense of Being. Bliss is the sense of the Beingness within beings (Bauer, $2019 \mathrm{~b}$ ).

The forms of a being may have affective, emotional and cognitive implications for the knowingness of minds. The experience of the forms of a being have affective, relational, emotional and experiential implication. The forms of a being have affective and emotional resonance. Form is a psychological experience. Form is an aesthetic experience. Form has emotional, relational and emotional implications for our experience of embodied mind.

The Being of beings has the resonance of the field of Being. The field of the Being of beings has and is a field of ontological resonance and attunement. We can experience within our awareness the resonance of the Being of beings. We can experience within our own awareness the 
resonance of Being itself. We are in resonance with the sphere of Being. The sphere of Being is the resonance of pure Being.

\section{Resonance of Mind and Resonance of Awareness}

There are two ways of resonance. There is resonance of Being and there is the resonance of our mind's affective and emotional States. Our mind of thinking, feeling, sensation, memory and imagination has emotional and affective states of resonance. Our mind is a series of emotional or affective states of relational resonance. Our mind has resonance to the minds of others. The minds of others have resonance to our mind.

Awareness is a relational field of the resonance of Being. There is also awareness of mind and the experiences of mind. Awareness experiences the resonance of Being and the dimensions of Being within beings and within the Being of phenomena. Awareness experiences the Being of phenomena and the phenomena of Being. Awareness also experiences the lack of Being and the absence of Being.

\section{One Knower}

Although there are two ways of knowing, naturally there is only one knower and there is the natural intertwining of mind and awareness. The natural union of mind and awareness brings forth the experience of the form of phenomena and the Being of the phenomena. Form of phenomena and the Being of the phenomena are known through the union of mind and awareness within the one knower. The form of phenomena is known through the mind and the Being of phenomena is known through awareness. As we unfold from childhood into adulthood for some the mind as the knower of form splits from awareness the knower of Being. 
A person who lives in mind only knows the form of phenomena and such a person may suffer the lack of the sense of presence of Being. For many, there is the loss of the Bliss of Being. Living in mind alone with a foreclosure on our awareness of Being, results in the loss of the presence of Being within our own self and within our experience of the world. As such a person, we may live without the sense of the Bliss of our Being and the Bliss of the Being of the world. Without the knowing of awareness the Bliss of Being is absent.

When we live within the intertwining of mind and awareness, we can experience affective responses within the context of the Bliss of Being. We can even feel pain within the context of the bliss of Being. We can feel hatred within the context of the bliss of Being. We can feel love and beloved-ness within the context of Being. We can experience shame within the Bliss of Being. We can experience afflictive emotions within the Bliss of Being. This is most important to know! Bliss is inclusive of the vast range of affective and afflictive feelings. The Bliss of Being does not exclude affective or afflictive experience as some would have you think. This limiting kind of religious thinking is distorted and dissociative.

We can integrate the mind and the functions of mind into and within the field of awareness which is the field of Being and the field of Bliss. The ongoing continuity of experience of Being is the experience of Bliss. If awareness disappears Bliss disappears. The mind can experience pleasure and pain but not Bliss. Bliss can infuse the mind and infuse the experience of the mind. The absence of Being as experience by awareness will feel like vast emptiness and have its own emotional terror for the mind. Sometimes for a person, such emptiness of Being, feels like a vast depression beneath depression. 


\section{Religion Mythologizes and Mystifies}

Religion mythologizes and mystifies the naturalistic direct knowing of awareness. Religion mythologizes and mystifies the direct knowing of Being. Religion moralizes the natural liberation of living naturally and immediately within the field of Being. The relentlessly patriarchal and theocentric context of religion institutionalizes the naturalistic experience of the Beatific-ness of our life experience of the field of Being. Religion likes to think it owns Bliss and is itself the source of the Purity of Bliss.

The transcendentalism of religion dissociates the beatific experience from the immediacy of ordinary life experience. Transcendentalism dissociates us from both the external phenomena of our being in the world, and from our experience of our innermost experience of our innermost sense of Being. This unhappy sequence of detachment can bring forth the experience that our living experience is unreal and the world itself is unreal and illusionary. All phenomena are considered by these transcendental religions as a distraction from the experience of the Purity of Being. Of course, this way of seeing is a tragic distortion of the natural experience of the field of Being as the source and as the selfmanifestation of phenomena.

Most of these religious transcendental traditions have dissociated mind from awareness, so that phenomena that are only known by mind are dissociated from the sense of Being. When the embodiment of awareness is foreclosed, the Bliss of Being is absent. In this dissociative context the Bliss of Being is often foreclosed (Bauer, 2020).

\section{Self-Liberation Through Bliss}

Religion mystifies the living within Being as Being by creating theologies of realization. These theologies of realization of God often 
described as requiring eons and eons of praxis in order for the great event to happen and take place. Life is waiting and waiting and more waiting. Waiting for Godot!

Religion and its relentless patriarchal institutionalization and Patriarchal domination as the One Who knows even implies the mystification of the power of granting this realization of Being or in their language the realization of God. This realization of Being is naturally given in everyone. The nature of Being itself gives the Bliss of Being to all beings, just as they are. This ontological gift of Being and the Beingness of Being is not the gift of some aging patriarchal male figure.

It is equally true that human beings have the power of the selfmanifestation of the light of their own awareness. All human beings have the power of timeless awareness in time. All human beings have the power of the compassionate transmission of the field of Being into another person.

\section{Chakrasamvara as A Tantra of the Realm of Immanence}

The Chakrasamvara Tantra invokes the archetypal power of experiencing the beatific experience within and as the realm of the immanence of Being. This means we can experience the beatific-ness of Being within our experience of beings, including our own being. We can experience all phenomena within the realm of the immanence as Pure Being. Our own Being is within the realm of immanence, the immanence of Pure Being. As a Shaivite person of long ago declared "the Bliss of Samadhi is the Bliss of the World".

We can experience through all and within all appearances the indivisibleness between appearance and Being, between being and Being itself. There is no difference of Being within and between beings. This 
luminous oneness of Being is the unfolding experience of beatific bliss. There is no ontological difference of Being within the phenomenological difference of beings. Being is univocal. Being is sameness, complete sameness within Being and within beings. The luminous oneness of Being is the unfolding experience of Beatific Bliss.

There is no ontological difference of Being within the phenomenological difference of beings. Being is univocal. Being is sameness, complete sameness within all beings. There is a difference within Forms, but not within Being.

\section{The Givenness of Being and The Givenness of Self Liberation}

The experience of the non-duality of our own Being as Being itself is self- liberating. This is the natural givenness of self- liberation within the unfolding of our life experience. Our life experience is the selfmanifestation of Being within us as us. Being is the self-manifestation of our life experience. The experience of the Beingness of my own Being liberates me from the containment of the various forms of experience. All my experience is the self-manifestation of Being as my own being. Being liberates me through the bliss of Being. My Being is Being itself becoming a being as me. The completeness of Being infuses my experience with bliss. The potentiality of Being is the potentiality of my own being which is my own innermost awareness. The bliss of my awareness is the bliss of Pure Being as a being.

The experience of the Being of my own being can be the experience of beatific-ness and the experience of my own Being can be my vision of beatific-ness that is completely within my field of Being. The experience of Being in and of itself is beatific-ness. The experience of the selfmanifestation of Being becoming my own being is the beatific experience. 
The experience of a being as Being itself is the beatific experience of selfliberation. To experience the Being of your own being and to experience the Being of another being is the beatific experience of Being. To experience the purity of Being in and of itself is the pure Beatific vision of the beatific experience. This does not mean human beings are not distorted in character and action. The purity of Being is beyond character and beyond action. To experience the purity of Being is always selfliberating from the containment of the forms of phenomena, the circumstances of phenomena and the containment of the character of phenomena. To experience the Being of phenomena is to experience the purity of phenomena.

To experience Beatific-ness is to experience the bliss of the Being of phenomena. Bliss is the experience of the Beatific-ness of the Being of phenomena. Beatific experience is in essence the Bliss of Being. Bliss and Beatific are completely correlational. The bliss of Being goes beyond right and wrong, goes beyond good and evil, goes beyond better and best and even goes beyond truth and falsity. Bliss is within us as our very Being which is Being itself. Bliss is innate. Bliss is the manifestation of the ground of Being. The ongoing continuity of experience of the manifestation of Being is Bliss. Self- liberation happens through the Bliss of our Being. Just as we are!

\section{The Gaze of Being and the Being of Our Gaze}

We can experience the field of Being of phenomena through our gaze. The gaze of our awareness is the gaze of and through the field of Being. The light of our gaze experiences the light of phenomena. The light of phenomena is the light of Being. The light of our gaze experiences the luminous Being of phenomena. The Being of phenomena and the Being 
of personhood is illuminated through our embodied gaze of our luminous embodied awareness. Our gaze is the gaze of our Being manifesting the illumination of the Being of phenomena as well as the character of phenomena. The gaze is not an objectified seeing of mind alone, but rather our gaze is the inter-subjective inside to inside self-illumination of Being of self and the Being of phenomena. The gaze of our Being illuminates the Being of phenomena. The gaze of our Being is the selfillumination of the light of our Being which is Being itself. The Gaze of Being is the Bliss of Being.

We gaze not with our eyes alone but we gaze from within the field of our fully embodied awareness. We gaze through our eyes, we gaze through our heart- mind continuum and we gaze through our fully embodied field of Being. The gaze of embodied awareness takes place within the field of immanence. The gaze of immanence is the gaze of gnosis, the direct knowing of Being within beings and the knowing of Being within phenomena.

This is pantheistic experience! This is naturalistic pantheistic experience of non-dual Being within the duality of beings. This is the naturalistic pantheistic experience of duality of beings within the nonduality of Being. This is the Bliss of Being as beings.

This experience of the gaze goes beyond the sense of sight as we have already described. The sense of this bliss filled knowingness permeates the sense of smell. A person who is embodying the field of Being may experience exquisite sense of fragrance arising within and around their body and the bodies of others.

This bliss filled direct knowingness of embodied being permeates the sense of touch. A person who is embodying the field of Being may experience the field through touch. This experience of bliss filled tactile- 
ness may both arise from touching and from being touched. Through tactile experience we touch the field of Being and are touched by and through the field of embodied Being. To use Merleau Ponty's metaphor we touch the flesh of Being. We touch the Being of flesh (Merleau-Ponty, 2013).

This bliss filled sense of direct knowingness fills our sense of sound. A person who has embodied Being and experiences the Bliss of Being may feel the permeability of their sense of hearing by sublime sounds and vibrational states of bliss filled experience.

This bliss full sense of knowing fills our sense of time within timelessness and our sense of timelessness within time. The sense of time itself becomes a most bliss full and permeating state.

Taste can be infused with Bliss full experience and energy of Bliss and so within the embodied field of Being a person can experience Amrita. As the sense of Amrita arises within us there is the inner sensuous experience of a sense of the rasa of liquid like taste permeating our embodiment. The inner chakras are filled with the sense of a taste of viscous sense of liquid light.

This bliss filled sense of field of Being can metabolize pain. The field of the bliss of Being can open contracted states of pain, dissolving the sensations of pain. The bliss filled opening of the field of perception results in pain no longer so completely dominating and organizing our sense of Being as self.

This bliss filled sense of Being can metabolize psychological suffering. The Bliss of Being infuses the sphere of suffering and this infusion profoundly unbinds us. The sense of Being converges with our sense of self. Our sense of Being and our sense of self are one. Our sense of self becomes the Bliss of Being. The sense of self is an onto cosmological 
sense of Being. Our sense of Being is the sense of Bliss. There are many doorways of this Bliss, and many events of Bliss. The sense of Bliss is the innate intrinsic sense of our innermost Being becoming. The Bliss of Being is always becoming and becoming and becoming.

In truth liberation is not a simplistic event. Liberation is not an All done event! Liberation is not a fixed state! Liberation is infinite in its becoming, life after life, death after death. Liberation of Being is forever and ever unfolding and forever and ever becoming and becoming. The universe is forever and ever unfolding and becoming. Being is becoming! Infinity is not a fixed state. Infinity is not bound in time or place. The religious understanding that realization and liberation is a time bound and time limited event is the form of reification and concretization of that which can never be reified and never concretized (Muktananda, 1978).

\section{Pure Land of Bliss Tradition}

The Chakrasamvara Tantra is deeply reflective of the ancient Pure Land tradition's description of the Pure Land of Bliss (Halkias, 2012). Of course, the Pure Land of Bliss is Sukhavati. As Ju Mipham in his commentary on his wonderful text "The Sun Like Instructions of a Sage" describes how our aspiration to dwell in the Pure Land of Bliss is of the essence. And secondly, to experience within our awareness the sense of the Light of Being is also of essence (Cook, 2016).

Many people think that Sukhavati is a pure land realm that only exists after death. This is not the truth of the realm of Sukhavati. From the esoteric Dzogchen view, Sukhavati exists both in our ordinary life realm, and as well as within the Sambogakaya realm while we are living in the Nirmanakaya realm. After death or after the time bound event of our dissolving from living within the Nirmanakaya realm, we dissolve into 
Sambogakaya realm which is the Realm of Rapture. This archetypal dimension is the Bliss of Rapture! The Bliss of Rapture is for everyone. Absolutely everyone. There is no exclusion of anyone who passes through the realm of death. We all dissolve into the realm of Rapture. This is the Pure Land of Bliss that is the nature of Rapture.

The great compassion of Being is infinite in its horizon, vast and inconceivable. The great compassion of Pure Being is not the concrete cruel judgmental-ness of the distorted Mind of Patriarchal Power and Patriarchal Priesthoods. Most religions are encapsulated in patriarchal institutionalization. The Great compassion is beyond good and evil, beyond right and wrong, beyond better and best and even, yes even beyond truth and falsity. The Dakini's delight within this luminous understanding.

This esoteric Dzogchen understanding is that the Pure Land of Bliss is the Buddha field. The Buddha field is not a person. The Buddha field in actuality is the experience of our non-dual nature of awareness. This non-dual field of primordial awareness is the source of the different dimensions of Being as well as actually being the different dimensions of Being. In becoming aware of awareness, we experience the Pure Land of Bliss. The Pure Land of Bliss is the Pure Field of the Bliss of the Being of our ordinary life realm, as well as the Pure Field of the Bliss of the Archetypal Sambogakaya realm and as well as the Pure Field of the Bliss of the realm of pure potentiality of the Dharmakaya.

By sense of the Light, Ju Mipham languages the Light of Being's selfmanifestation as the Buddha Amitabha. Of course, the Buddha Amitabha is not a person but the archetypal light of Being manifesting itself in "us as us". Ju Mipham says explicitly that entering and dwelling in this Pure land is not for a later time. He is implying the land of Pure 
Bliss is Now. The Presence of the Pure Land of Bliss is Now, always and forever Now. You will always exist in nowness.

Ju Mipham further describes how dwelling in this land of Pure Bliss does not depend on merit and does not depend on our accomplishments such as being a Bodhisattva. There are no required conditions to enter the pure land of Bliss. And most of all Being in the Pure Land of Bliss does not require death. The Pure Land of Bliss is not simply an afterdeath moment or after death realm. The Pure Land of Bliss is here and now. The Pure Land of Bliss is here and now life after life and death after death. The Pure Land of Bliss is timeless awareness becoming time. Timelessness awareness is always manifesting and becoming time forever and ever.

This pure land of Bliss is the presence of the Pure Field of Being in "you as you". You are always in this field of Being, life after life and death after death. Being is the Pure Land of Bliss. This Pure land of Pure Bliss is present now as this life. This Pure Land of Pure Bliss is present, as you dissolve through the doorway of death. From being located in the ordinary life world of the Nirmanakaya dimension of Pure Being, through the doorway of dying you move into the Pure Bliss of Sambogakaya dimension of the Pure Being of great rapture. This Pure Land Realm of Bliss is described as the Pure Land of Bliss in early Sacred Text of Mahayana.

You may then dissolve further into the Bliss of Pure Being of Dharmakaya dimension, the realm of Pure Potentiality of Pure Being. This is the Pure Realm of Pure Being of Pure Bliss of Potential Space. In time you may again manifest in the ordinary life world realm, as well as remaining in the archetypal realm of the Sambogakaya dimension of Pure Land of Bliss. 
You may wonder as you experience Ju Mipham's understanding that the nature of Pure Lands of Bliss is existentially so available and existentially so present. Why then is the experience of the Bliss of Being so hidden and so obscured for so many?

Ju Mipham does focus on the power of self-effort as well as the power of the field of Being to bring forth the Pure Land experience. Self-effort seems to be in the Dharma of aspiration and attunement to the field of Being/awareness in the different dimensions of the Kaya's.

\section{Conclusion}

The compassionate power of the field of Being/awareness is the luminous power of the field within its different dimensions and manifestations of and as the Kaya's. The power of the field of Being which is the power of the Pure Land of Bliss, liberates us naturally. The Pure Land of Bliss is beyond right and wrong, good and evil, better and best and even truth and falsity. The Pure Land of Bliss is beyond the truth as Judgement. The Pure Land of Bliss is the truth of self-revelation and selfillumination. The field of Being reveals itself to us as us. The Pure Land of Bliss is the field of Being in the self-revelation of its essence.

The Pure Land of Bliss is totally free of patriarchal distortion and the theocentric confusion of royalty and spirituality. The pure land of Bliss is totally free of the distorted confusion of the aberrational theocentric judgement of heaven and hells, of torture and liberation, of rewards and everlasting punishment by unending torture. The Pure Land of Bliss is free of the patriarchal relentless love of torture and relentless unending cruelty for the sake of their "would be" God, who is simply the mirror of their own mind. 
The Pure Land of Bliss is the nature of Being. The pure land of Bliss is one voice. The Pure Land of Bliss is equality consciousness. The Pure land of Bliss is the pure Being of awareness being unborn and undying. The Pure Land of Bliss is manifest in all circumstance, all context, all situations and all events of Being. Within every event is the Bliss of the radiance of Being. 


\section{References}

Bauer, R. (2019). Mind As Knower of Forms, And Awareness as The Knower of Being: A Phenomenological View. MenteClara Foundation's Peer-reviewed Journal, Vol.4 (2), 47 53. doi: https://doi.org/10.32351/rca.v4.2.86 See at:

https://fundacionmenteclara.org.ar/revista/index.php/RCA/article/view/86

Bauer, R. (2019). Ontology of Bliss: A Phenomenology. MenteClara Foundation's Peerreviewed Journal, Vol.4 (2), 55-70. doi: https://doi.org/10.32351/rca.v4.2.87 See at: https://fundacionmenteclara.org.ar/revista/index.php/RCA/article/view/87

Bauer, R. (2020). Human Egalitarianism and the Patriarchal Illusion: A Phenomenological View. MenteClara Foundation's Peer-reviewed Journal, Vol.5 (122). doi: https://doi.org/10.32351/rca.v5.122 See at: https://fundacionmenteclara.org.ar/revista/index.php/RCA/article/view/122

Capobianco, R. (2014). Heidegger's Way of Being, University of Toronto Press.

Cook, L. (2016). JU MI PHAM ON PURE LAND DOCTRINE AND PRACTICE, Master of Arts Thesis Advisor: James Gentry Centre for Buddhist Studies, Kathmandu University.

Gray, D. B. (2007). The Cakrasamvara Tantra (The discourse of Srī Heruka). American Institute of Buddhist Studies.

Halkias, G. T. (2012). Luminous Bliss: a religious history of Pure Land literature in Tibet. University of Hawai'i Press.

Merleau-Ponty, M. (2013). Phenomenology of perception. Routledge.

Morris, David (2018) Merleau- Ponty's Developmental Ontology, North Western University Studies In Phenomenology and Existential Philosophy, Northwestern University Press, Evanston, Illnois.

Muktananda, S. (1978). Play of consciousness. Harper \& Row. 